\title{
LATEST SILURIAN (OHESAARE STAGE) CONODONTS AND THE DETORTA ZONE IN THE NORTHERN EAST BALTIC
}

\begin{abstract}
Viive VIIRA
Institute of Geology, Tallinn Technical University, Estonia pst. 7, 10143 Tallinn, Estonia; viira@gi.ee

Received 22 June 1999, in revised form 22 September 1999

Abstract. The latest Silurian conodonts from the Sõrve Peninsula of Saaremaa Island, Ruhnu Island, and western Latvia include Ozarkodina remscheidensis remscheidensis, $\mathrm{Oz}$. confluens, $\mathrm{Oz}$. nasuta, and Oulodus elegans. They represent the local nearshore remscheidensis remscheidensis Subzone of the remscheidensis Zone. The Oulodus elegans detorta Zone occurs as a short interval in the upper part of the Ohesaare Stage. Three new species are described: Amydrotaxis? praecox, $\mathrm{Oz}$. denticulata, and $\mathrm{Oz}$. inordinata. Ozarkodina nasuta (Viira, 1983) was originally described as the subspecies of $O z$. confluens.
\end{abstract}

Key words: conodonts, taxonomy, biostratigraphy, Upper Silurian, East Baltic.

\section{INTRODUCTION}

The Oulodus elegans detorta Zone is the youngest Silurian conodont zone. It represents a very short time interval in the post-Monograptus transgrediens interregnum and is known to be widespread in strata of this age (Jeppsson 1988). The subspecies Oul. elegans detorta was identified from the highest level of the Beyrichenkalk by Jeppsson (1975). A characteristic feature of this subspecies is denticles of variable size on the posterior process of the Sc element and/or of some other elements. Oul. elegans elegans has denticles normally distally increasing evenly in size on all elements.

Jeppsson et al. (1994) established the presence of the index species Oul. elegans detorta in the Ohesaare cliff section of Saaremaa Island, Estonia. This 
has given rise to the discussion concerning the distribution and range of the detorta Zone in the East Baltic. The aim of the present paper is to characterize the zone and to describe the accompanying conodont fauna in the northern East Baltic. The Pridoli in the northern East Baltic is characterized by shallow-water deposits formed during the Late Silurian regression (Kaljo 1970; Nestor \& Einasto 1997). These rocks belong to two facies belts: shelf in the west and the transitional belt (basin slope) in the east (Kaljo \& Jürgenson 1977; Bassett et al. 1989). Shelf deposits are represented by different types of skeletal limestones. In the transitional belt marlstones and argillaceous limestones dominate. The fauna of these beds is rich, containing brachiopods, crinoids, ostracods, agnathans, vertebrates, corals, and bryozoans on the shelf and molluscs and trilobites in the transitional belt. Due to low water and instability of the bottom, intercalation of neighbouring facies has often taken place.

Stratigraphically, the Pridoli comprises the Kaugatuma and Ohesaare stages which are represented by the Kaugatuma and Ohesaare formations on the Sõrve Peninsula and by the Minija and Targale formations in western Latvia. In this paper some of the conodonts from the uppermost Pridoli Ohesaare Stage are desribed, mainly from the Ohesaare and Targale formations (Figs. 1, 2).

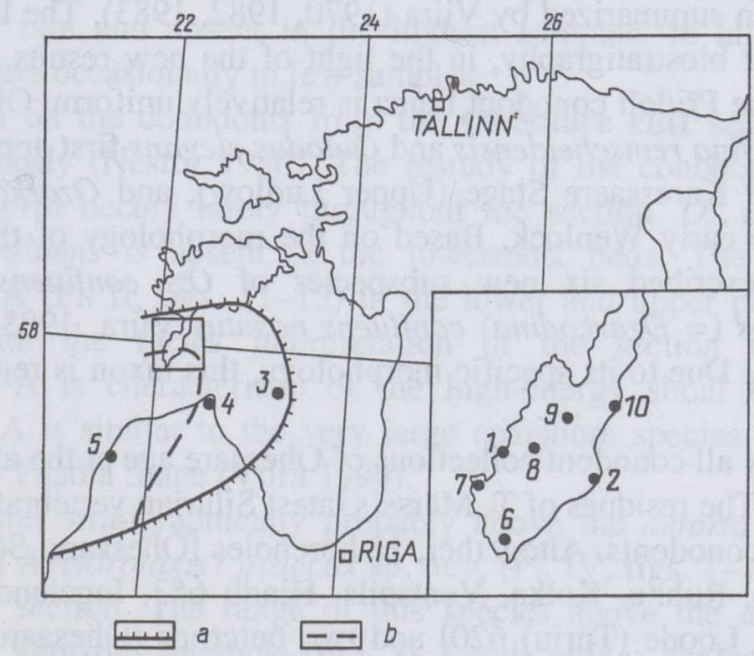

Fig. 1. Location of boreholes. 1, Ohesaare and Ohesaare 2 boreholes, and Ohesaare cliff; 2, Kaavi 568, Kaavi 571; 3, Ruhnu; 4, Kolka; 5, Ventspils; 6, Sõrve 514; 7, Loode 620; 8, Kargi 623; 9 , Ingeland $618 ; 10$, Hindu 653 . Loode cliff is about $10 \mathrm{~km}$ to the south from Ohesaare cliff. a, boundary of the present extension of the latest Silurian rocks; b, boundary of the shelf and transitional facies belts (after Bassett et al. 1989; Nestor \& Einasto 1997). 


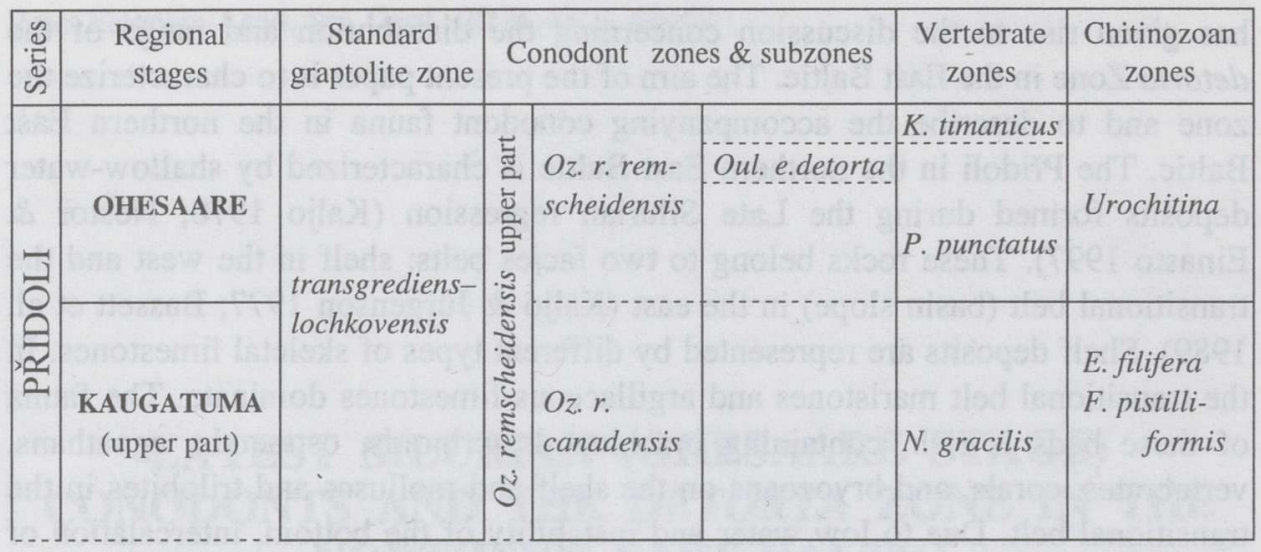

Fig. 2. Stratigraphy and correlation of the latest Silurian biozones. Vertebrate zones are given after Märss (1997) and chitinozoan zones after Nestor (1992) and Nestor (1997). Oz., Ozarkodina; Oul., Oulodus; $r$, remscheidensis; e, elegans; K., Katoporodus; P., Poracanthodes; N., Nostolepis; E., Eisenackitina; F., Fungochitina.

\section{BIOSTRATIGRAPHY}

The general outline of the conodont succession in the East Baltic Upper Silurian has been summarized by Viira $(1970,1982,1983)$. The late Ludlow and Pridoli conodont biostratigraphy, in the light of the new results, is discussed in Viira (1999). The Pridoli conodont fauna is relatively uniform. Of the three main species, Ozarkodina remscheidensis and Oulodus elegans first appear at the lower boundary of the Kuressaare Stage (Upper Ludlow), and Ozarkodina confluens ranges from the early Wenlock. Based on the morphology of the $\mathrm{Pa}$ elements, Viira (1983) described six new subspecies of $O z$. confluens, among them Spathognathodus (= Ozarkodina) confluens nasutus Viira, 1983 from the Ohesaare Formation. Due to its specific morphology, this taxon is regarded here as a distinct species.

For this study all conodont collections of Ohesaare age at the author's disposal were restudied. The residues of T. Märss's latest Silurian vertebrate samples were also picked for conodonts. Altogether, 12 boreholes [Ohesaare, Sõrve 514, Kaavi 568, Kaavi 571, Ruhnu, Kolka, Ventspils, Hindu 653, Ingeland 615, Ingeland 618, Kargi 623, Loode (Türju) 620] and two outcrops (Ohesaare, Loode) reach the uppermost Silurian. The outcrops and most of the boreholes are situated on the Sõrve Peninsula of Saaremaa; the Kolka and Ventspils boreholes are in Latvia and the Ruhnu borehole on Ruhnu Island in the Gulf of Riga (Fig. 1). The samples used for this study were of different sizes. Most samples from the Ohesaare, Kolka, and Ventspils boreholes were about 1-1.5 kg each, but the samples from some other cores weighed only about $0.2-0.3 \mathrm{~kg}$. The number of conodonts per sample varied largely from a single specimen to several hundreds. 
Further, samples with beautifully preserved delicate conodonts alternated with samples where many elements were broken. For instance, large specimens were generally fragmented and in some cases rounded.

In all studied sections species of Ozarkodina (Figs. 3, 4) form the main fauna. Ozarkodina remscheidensis is represented by $O z . r$. remscheidensis (PI. I, figs. 1-5, 8-11) which gradually replaces $O z . r$. canadensis and becomes prevalent near the lower boundary of the Ohesaare Stage. Ozarkodina nasuta (PI. II, figs. 1, 3-5) appears after an interval lacking $O z$. confluens (Pl. II, figs. 2, 6-9, 10). The third most frequent species is Oulodus elegans (PI. I, figs. 12, 15), which is mainly represented by Oul. e. elegans and rare specimens of Oul. e. detorta (PI. I, figs. 13, 14). The elements of Oul. elegans show some morphological variation (curvature, size, closeness of denticles) from sample to sample.

Silurian conodonts from the Ohesaare and Ohesaare 2 boreholes (Fig. 3) have earlier been studied by Viira $(1977,1982)$. The Ohesaare Stage is represented in the Ohesaare 2 borehole; the Ohesaare borehole ends with the Kaugatuma Stage. In Ohesaare 2 the most numerous taxon is Oul. elegans. Ozarkodina remscheidensis is represented by $O z . r$. canadensis in the lower part of the studied section and $\mathrm{Oz}$. r. remscheidensis in the upper part. Ozarkodina nasuta is relatively rare, except in the uppermost sample at $3.15 \mathrm{~m}$. A few small $\mathrm{Pa}$ elements of $\mathrm{Oz}$. inordinata sp. nov. (Pl. III, figs. 1-5) have been recovered from $6.85 \mathrm{~m}(? 10.05 \mathrm{~m})$ and upwards in Ohesaare, and from 7.40 and $3.15 \mathrm{~m}$ in Ohesaare 2. This taxon occurs also in almost all other sections. Elements of Panderodus are rare and absent in the highest samples. In all other sections Panderodus occurs occasionally in few samples.

Selected data on the conodonts from the Ohesaare cliff section have been published previously (Nestor 1990). The restudy of the conodont fauna shows that $O u l$. e. detorta occurs rarely throughout the section. Oz. nasuta prevails, whereas $O z$. confluens is absent in the lowermost beds. The occurrence of Ozarkodina sp. A (Pl. II, figs. 11-13) in the lower and upper parts of the cliff agrees well with the facies interpretation of the section (Nestor 1990). Ozarkodina sp. A is characteristic of the high-energy shoal belt. In a way Ozarkodina sp. A is similar to the very large nearshore species $O z$. roopaensis from the Ludlow Paadla Stage (Viira 1994).

Loode cliff lies stratigraphically probably above the detorta Zone, judging from the finds of Amydrotaxis? praecox sp. nov. (Pl. IV, figs. 1-10) in the upper part of the cliff section. The range of this species above the detorta Zone is known from the Ventspils borehole (Fig. 3). Loode cliff is characterized also by rather numerous $O z$. nasuta and Ozarkodina sp. A.

The Kaavi 568 and Kaavi 571 borehole sections pass through the uppermost Silurian beds, including domerites of the Kaavi Member (Aaloe et al. 1976). The Kaavi 568 section starts at $60.2 \mathrm{~m}$, where still Oz.r. canadensis and already $O z$. nasuta are present. Oz.r. remscheidensis appears at $50.15 \mathrm{~m}$. The replacement of $O z . r$. canadensis by $O z . r$. remscheidensis took place here later than in other 


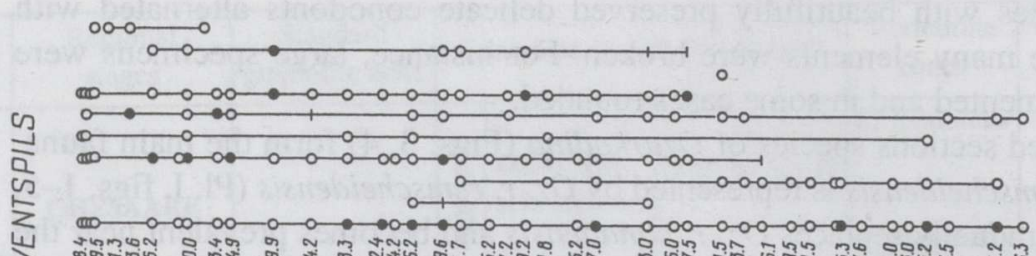
NOII $1 W \forall O J \quad \exists 7 \forall 9 \forall \forall \perp$
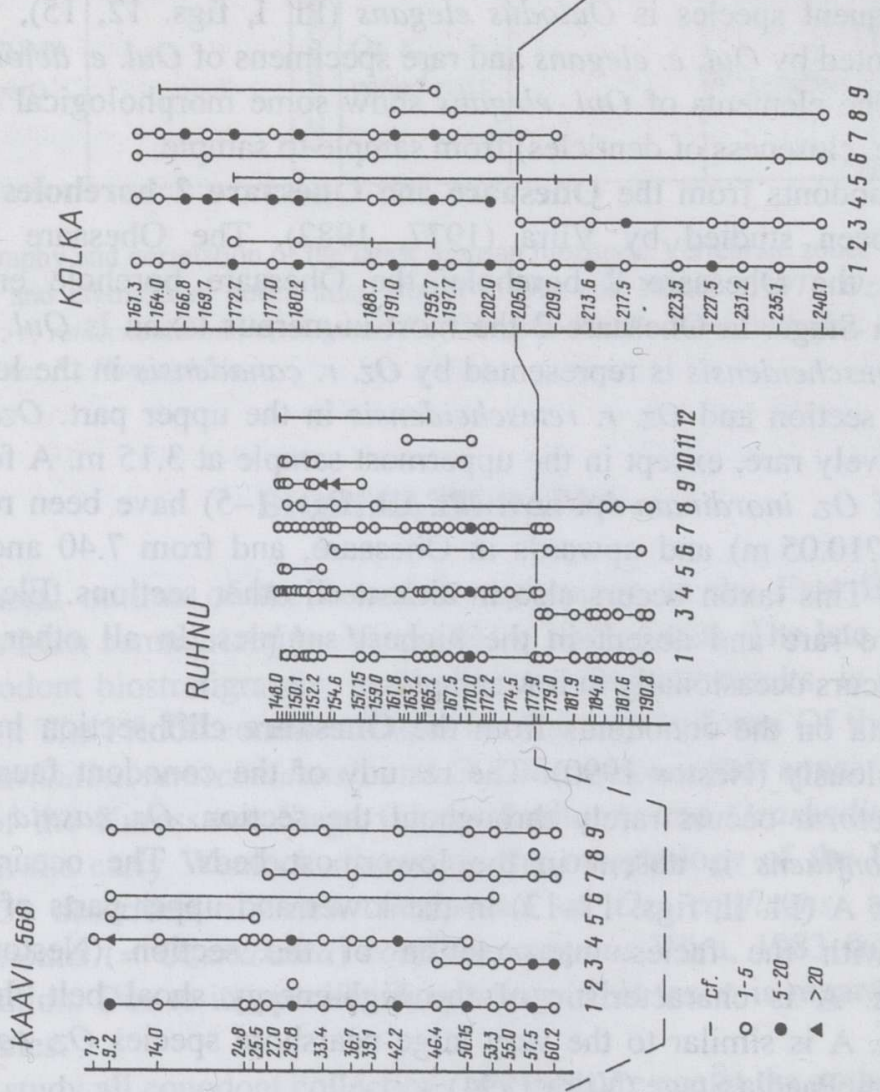

รี กิ

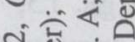
त宓: 항 के

氙:

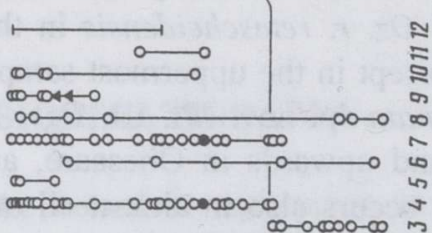
I

崩

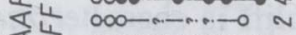
(I) $100000000000-$ I $5+a$

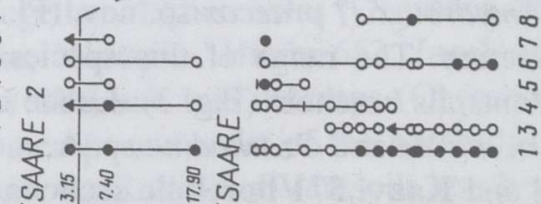
心

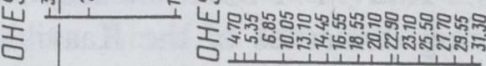



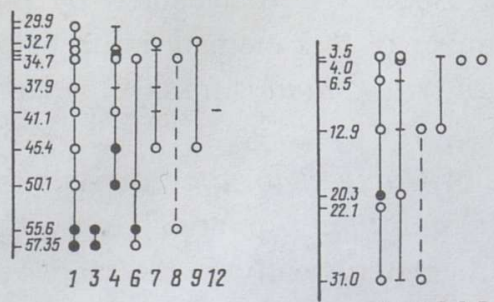

145789

KARGI 623

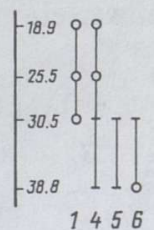

1456
INGELAND 618

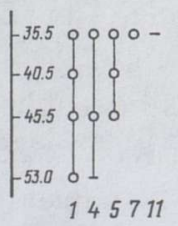

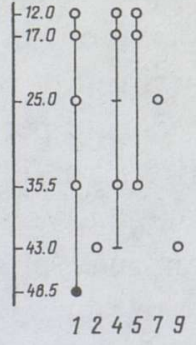

Fig. 4. Ranges of conodont species in the boreholes with short sections. Depths are given in metres. For legend see Fig. 3.

sections. Unlike other boreholes and outcrops, a specific morphologic type of Oz. r. remscheidensis ( $\mathrm{Pl}$. I, figs. 6,7) occurs in the two uppermost samples from the Kaavi 568 section, and also in samples from 12.0 and $13.3 \mathrm{~m}$ in the Kaavi 571 section. Pa elements of this morphotype differ from the corresponding elements of other subspecies in having a rather long blade and a well developed high anterior part of the blade. This taxon is similar to Oz. remscheidensis from the type locality in the Lower Devonian Hüinghäuser Schichten of the Rhenisch Schiefergebirge (Ziegler 1960). Besides, the specificity of the fauna of the Kaavi Member is emphasized by the occurrence of $O z$. confluens and the absence of $O z$. nasuta, which is common in the uppermost Silurian sections. These $\mathrm{Pa}$ elements of $\mathrm{Oz}$. confluens (Kaavi 568, $9.2 \mathrm{~m}$ and Kaavi 571, $12.0 \mathrm{~m}$ ) are characterized by a long blade and two large denticles situated centrally and separated by one or two small denticles. In the uppermost Kaavi samples elements of Oulodus elegans as well (especially Sc element) have a specific character - a ledge on the basal part of the processes.

In the Ruhnu borehole the number of conodonts per sample is rather low, which is partly caused by the small weight of the samples. In spite of this, the diversity of conodont taxa is rather high. The morphology of the $\mathrm{Pa}$ element of $O z$. $r$. remscheidensis varies considerably: $\mathrm{Pa}$ specimens are very short in the sample at $166.3 \mathrm{~m}$, have few wide denticles in samples at 165.2, 171.9, and $172.6 \mathrm{~m}$, and are small, with a big central denticle at 148.1, 153.9, and $157.15 \mathrm{~m}$. $\mathrm{Oz}$. denticulata sp. nov. (PI. III, figs. 6-8) with numerous narrow, fused denticles on the $\mathrm{Pa}$ elements (interval 149.1-169.3 m) is typical of this section. The interval 148.0-157.15 m contains rather numerous relatively large fragments of Ozarkodina sp. A, some of which have rounded outlines. Specimens, tentatively assigned to the Lower Devonian genera Streptotaxis? sp. (170.0 m) (Pl. IV, figs. 13, 14) and Amydrotaxis? cf. praecox sp. nov. $(165.2,166.3$, and $? 148.1 \mathrm{~m})$ occur in the upper part of the Ruhnu section. An Sc element was identified as Oulodus elegans cf. Oul. e. detorta in the sample at $150.2 \mathrm{~m}$. 
The Kolka borehole section is important, because Oul. e. detorta occurs here in four samples and shows the interval of the detorta Zone in the Ohesaare Formation. In each of these samples the index species is represented by one specimen of the Sc element, while the total number of this element is up to 36 specimens per sample. A big carminate element of Ozarkodina is found at a depth of $180.2 \mathrm{~m}$ (Pl. IV, fig. 12).

In the Ventspils borehole as well the range of Oul. e. detorta constitutes the zone interval, from 306.2 to $333.0 \mathrm{~m}$. Ozarkodina inordinata sp. nov. has a wider stratigraphic range here than in other sections. Characteristically, in the ranges of $O z$. r. canadensis and Oz.r. remscheidensis the replacement of the former by the latter takes place over a rather wide interval. A specific, twisted digyrate element of Oulodus is found at $298.9 \mathrm{~m}$ (Pl. IV, fig. 11).

The boreholes in Fig. 4 represent different stratigraphical levels of the Ohesaare Stage. Oul. e. detorta was identified only in the Hindu 653 borehole at a depth of $43.0 \mathrm{~m}$.

To summarize the distribution of the conodonts, the two specific characters of the fauna should be stressed. First, the conodont fauna of the Ohesaare Stage shows a great diversity of the genus Ozarkodina. The genus includes two groups of apparatuses representing two different lineages $-O z$. confluens and Oz. remscheidensis. In addition to the common Oz.confluens, Oz. nasuta and Ozarkodina sp. A occur in the $O z$. confluens group. The species $O z$. nasuta is present in all sections of Ohesaare age. Ozarkodina sp. A is numerous in the uppermost part of the Ruhnu borehole and in the Loode outcrop but is found also in other sections. The widespread species of the other group Oz. remscheidensis differs from its close relatives $\mathrm{Oz}$. denticulata sp. nov. and $\mathrm{Oz}$. inordinata sp. nov. chiefly in the $\mathrm{Pa}$ element. Second, there occur species with the so-called Devonian appearance - Amydrotaxis? praecox sp. nov., Streptotaxis? sp., and Kaavi-type $O z$. r. remscheidensis.

\section{Explanation of Plate I}

Figs. 1-5, 8-11. Ozarkodina remscheidensis remscheidensis (Ziegler), Pa elements. 1-5, Cn 1564, Cn 1584-Cn 1587; Kaavi 571 borehole, 1 - depth 11.60 m, 2-5 - depth $13.30 \mathrm{~m}$; all $\times 50.8,9,11$, Cn 1590-Cn 1592; Loode cliff, sample 1; 8, $9 \times 40,11 \times 50.10$, Cn 1563; Loode cliff, sample 4; $\times 40$.

Figs. 6, 7. Ozarkodina remscheidensis ssp., Pa elements. 6, Cn 1588; Kaavi 571 borehole, depth $11.60 \mathrm{~m} ; \times 50.7, \mathrm{Cn} 1589$; Kolka borehole, depth $172.2 \mathrm{~m} ; \times 50$.

Figs. 12, 15. Oulodus elegans elegans (Walliser). 12, Pa element, Cn 1593; Loode cliff, sample 3; $\times 50.15$, Sc element, Cn 1596; Ohesaare cliff, sample XXII; $\times 50$.

Figs. 13, 14. Oulodus elegans detorta (Jeppsson), Sc elements. 13, Cn 1594; Ohesaare cliff, sample XXII; $\times 50.14$, Cn 1595; Ventspils borehole, depth $306.2 \mathrm{~m} ; \times 50$. 


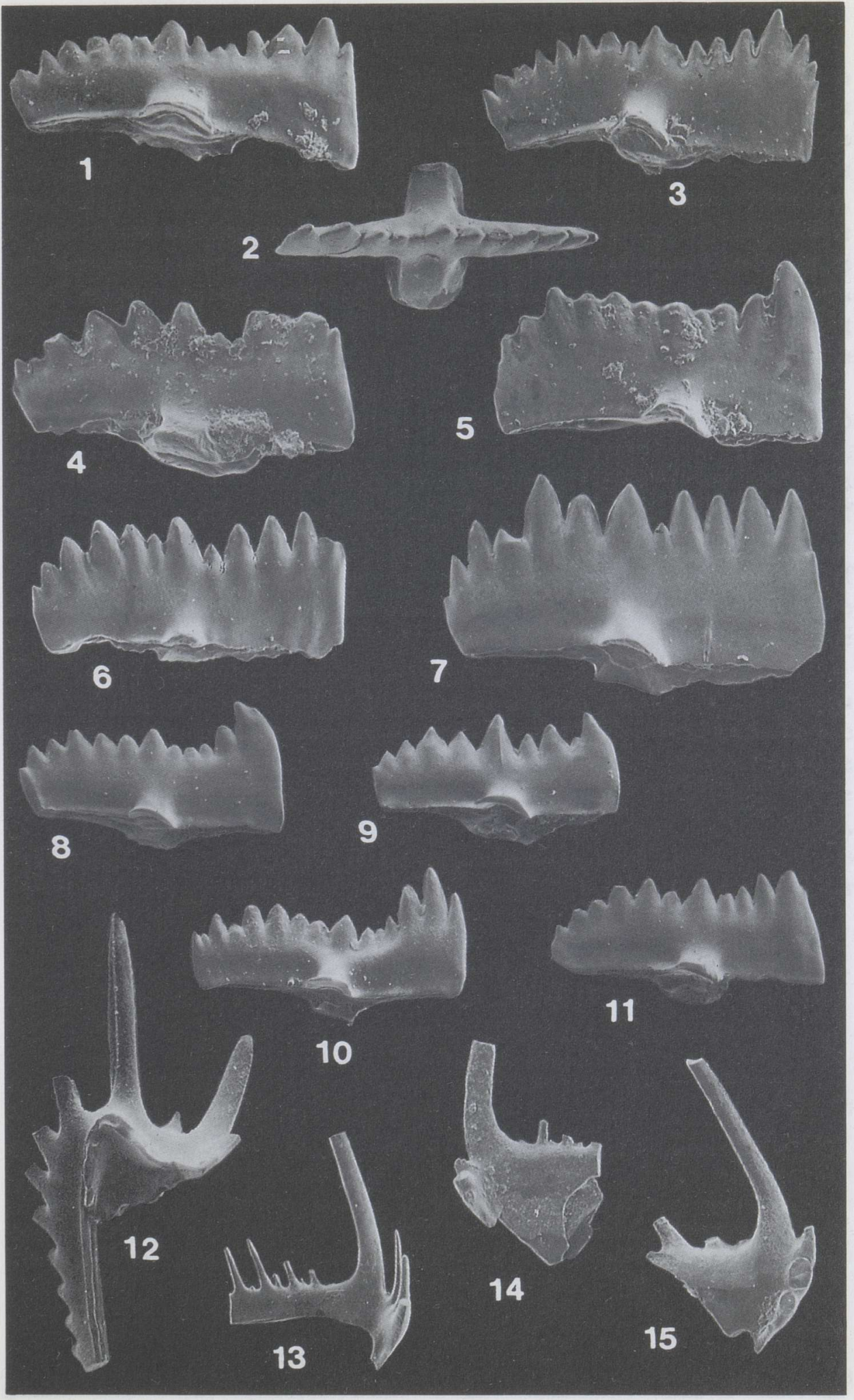




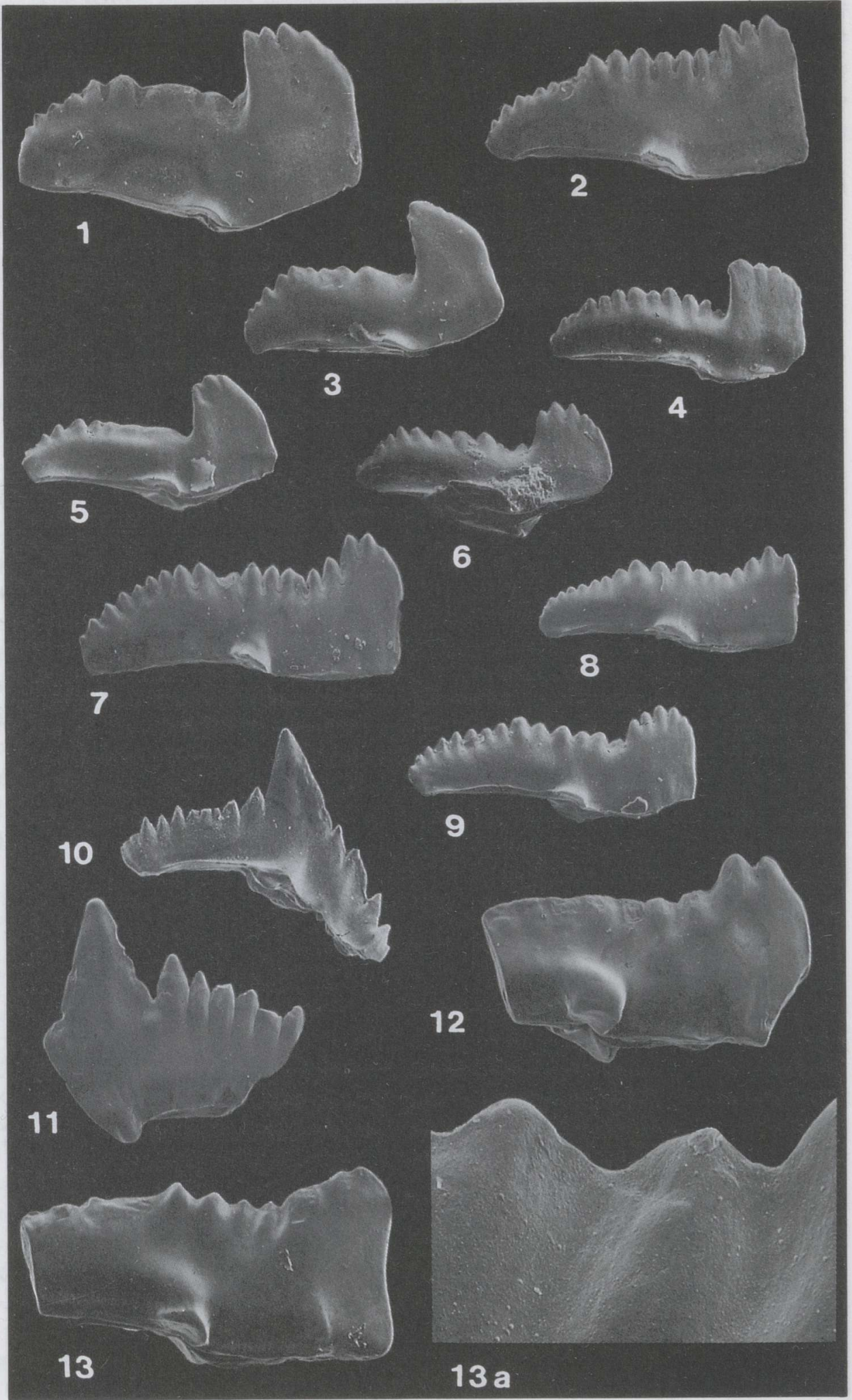




\section{CORRELATION}

One of the purposes of this study was to establish the interrelationship between the conodont and vertebrate zonations in the latest Silurian of the East Baltic (Fig. 2). The detorta Zone was determined besides Ohesaare cliff in the Ventspils, Kolka, Ruhnu, Kaavi 568, and Hindu 653 sections, where it falls within the interval of the Poracanthodes punctatus thelodont Zone (Märss 1986). The "Devonian" species Amydrotaxis? praecox sp. nov. came from the part of the Ventspils section which is above the detorta conodont Zone and lies in the Katoporodus timanicus vertebrate Zone. The Turinia pagei vertebrate Zone has its lowest occurrence at Ventspils at $269.5 \mathrm{~m}$ (Märss 1986), where the last specimens of $A$. ? praecox sp. nov. occur. This vertebrate zone indicates the base of the Devonian according to Märss (1997).

The detorta Zone falls within the local Urochitina chitinozoan Zone and in the global Anthochitina superba chitinozoan Zone (Nestor 1992; Verniers et al. 1995). Anthochitina superba Eisenack has been identified by V. Nestor in the Ventspils sample at $336.2 \mathrm{~m}$, which is just below the first occurrence of Oul. e. detorta (Gailite et al. 1987).

Defining the detorta Zone, Jeppsson (1988) stated that the upper boundary of the zone may coincide with the base of the first Devonian conodont zone, the Icriodus woschmidti Zone. In the northern East Baltic, however, the detorta Zone does not reach the uppermost Silurian.

In summary: the biostratigraphic study of conodonts shows that the detorta Zone in the East Baltic ranges through a short interval in the upper part of the Ohesaare Stage but does not reach the uppermost Silurian beds. In addition to the rare index subspecies, more numerous specimens of the typical subspecies are always present. The Oul. e. detorta Zone lies in the range of Oz. nasuta, $O z$. r. remscheidensis, and Oz. inordinata sp. nov. Ozarkodina nasuta appears in the uppermost Kaugatuma Stage above the interregnum in the Oz. confluens range.

\section{Explanation of Plate II}

Figs. 1, 3-5. Ozarkodina nasuta (Viira), Pa elements. 1, 3-5, Cn 1597, Cn 1599, Cn 1579, Cn 1600; Loode cliff, samples 5, 2, 4, 1; $1 \times 50,3-5 \times 30$.

Figs. 2, 6-9, 10. Ozarkodina confluens (Branson \& Mehl). 2, 6-9, Pa elements; 10, Pb element. 2, 6, 8, 9, Cn 1598, Cn 1601, Cn 1603, Cn 1604; Loode cliff, samples 5, 2, 1, 3. 7, Cn 1602; Ohesaare cliff, sample X. 10, Cn 1605; Loode cliff, sample 6; 2, $10 \times 30,6 \times 40,7-9 \times 20$.

Figs. 11-13. Ozarkodina sp. A. 11, Pb element; 12, 13, Pa elements; Cn 1606-Cn 1608; Ohesaare cliff, sample XV; 11-13 × 20,13a $\times 90$. 


\title{
SYSTEMATIC PALAEONTOLOGY
}

Class CONODONTA Eichenberg, 1930 sensu Clark, 1981

Order OZARKODINIDA Dzik, 1976

Family SPATHOGNATHODONTIDAE Hass, 1959

Genus Amydrotaxis Klapper \& Murphy, 1980

\author{
Amydrotaxis? praecox sp. nov. \\ Plate IV, figures $1-10$
}

Holotype. Pa element, Cn 1617; Pl. IV, fig. 1.

Type locality. Loode cliff, Sõrve Peninsula of Saaremaa Island.

Type horizon. Ohesaare Stage, upper Pridoli.

Derivation of name. The specific name refers to the stratigraphically early appearance of this species.

Material. $8 \mathrm{~Pa}, 3 \mathrm{~Pb}, 2 \mathrm{M}, 1 \mathrm{Sa}, 2 \mathrm{Sb}, 3 \mathrm{Sc}$.

Diagnosis. $\mathrm{Pa}$ element with asymmetrical platform lobes developed in the posterior half of the blade. Wide denticles nearly uniform; processes of $\mathrm{Pb}$ element short, especially posterior one.

Description. $\mathrm{Pa}$ element is robust, spathognathodiform, with straight and moderately thick blade. The element has 8-12 low and wide denticles of nearly uniform size. Anterior end of the blade is slightly higher, anterior edge curved straight upwards. Posterior end decreases gently in height. Basal margin straight, with downward extended posterior end. Basal cavity located posteriorly. Basal lobes flared asymmetrically to lateral sides and tapering towards posterior end. From the basal pit a narrow groove extends to the aboral posterior end.

$\mathrm{Pb}$ element has a prominent cusp and short laterally compressed processes. Posterior process is shorter than the anterior one. They may have up to 4 denticles which are wide in lateral view. Edges of the cusp and denticles sharp. Anterior process moderately curved inwards and downwards. Rather shallow basal cavity is beneath the cusp and extends as narrow grooves to the ends of the processes.

\section{Explanation of Plate III}

Figs. 1-5. Ozarkodina inordinata sp. nov., Pa elements. 1, Cn 1609; Loode cliff, sample 5. 2-4, Cn 1610-Cn 1612; Kolka borehole; 2 - depth 213.6 m, 3, 4 - depth 180.2 m. 5, Cn 1613; Kaavi 571 borehole, depth $11.60 \mathrm{~m} .1 \times 60 ; 2-5 \times 75 ; 5 \mathrm{a} \times 220$.

Figs. 6-8. Ozarkodina denticulata sp. nov., Pa elements. 6, 7, Cn 1614, Cn 1615; Ruhnu borehole, depth $148.6 \mathrm{~m}, 152.2 \mathrm{~m}$. 8, Cn 1616; Hindu 653 borehole, depth $48.5 \mathrm{~m} .6,8 \times 60 ; 7 \times 75$; $6 \mathrm{a} \times 175 ; 8 \mathrm{a} \times 230$. 

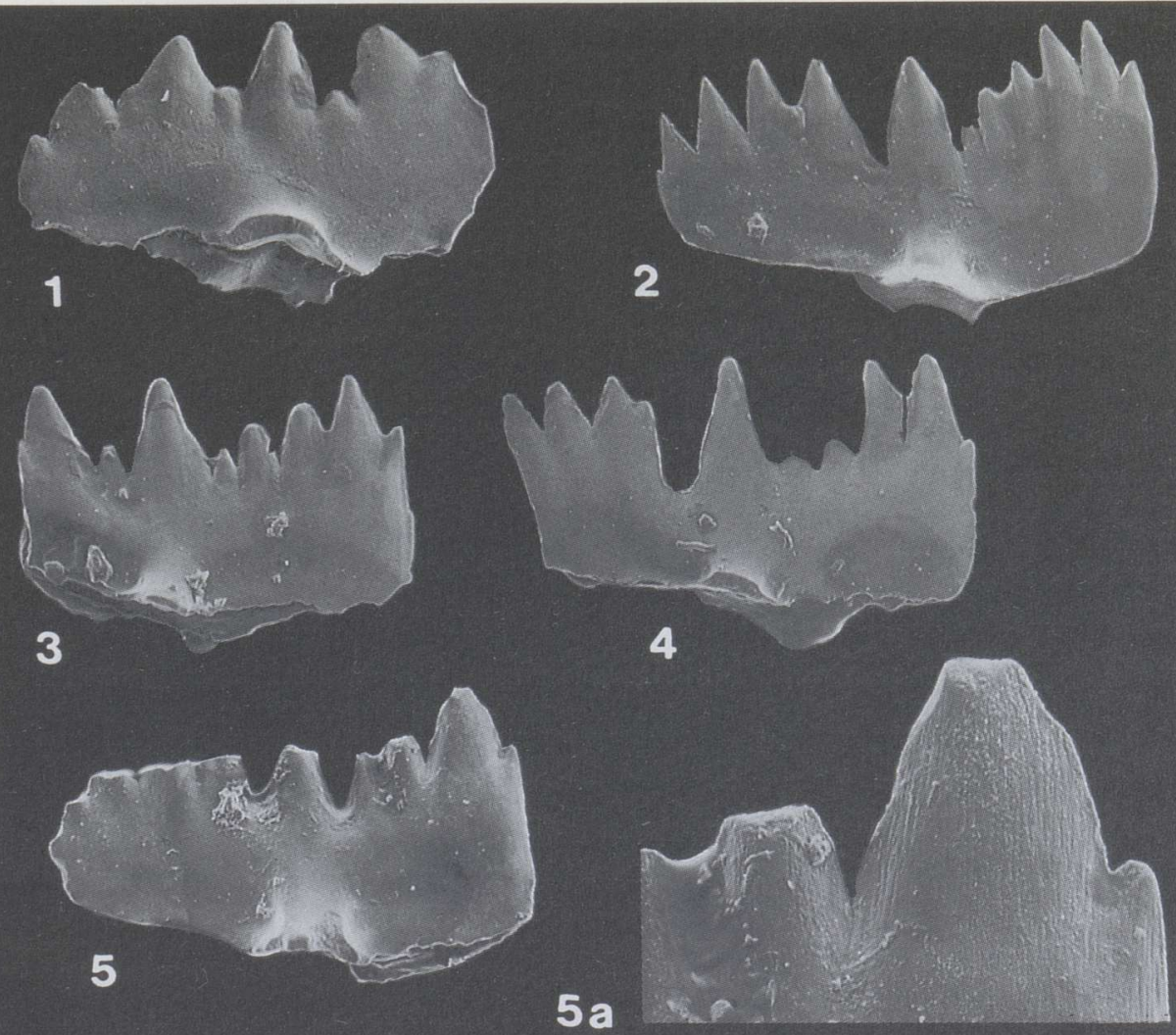

\section{$5 a$}
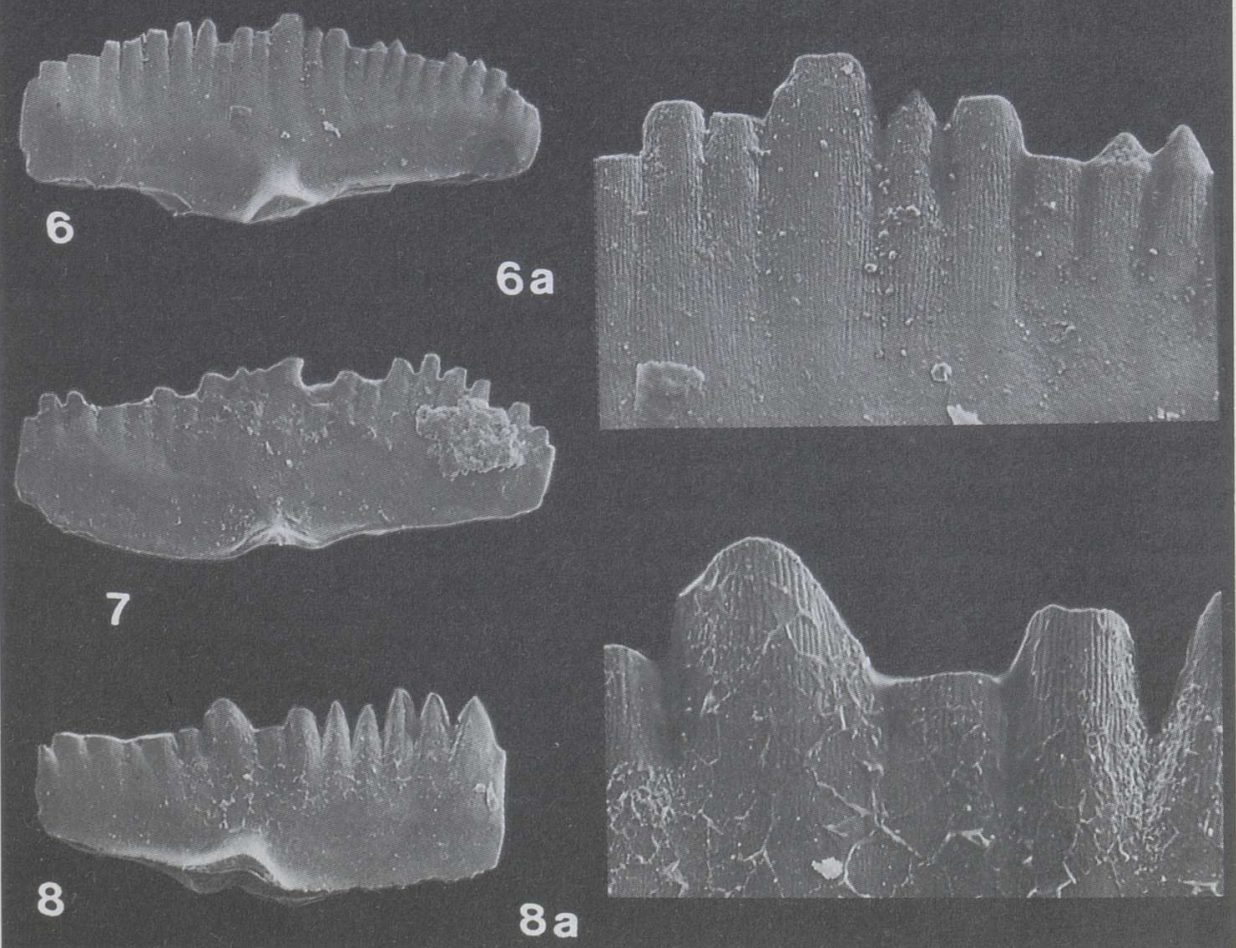


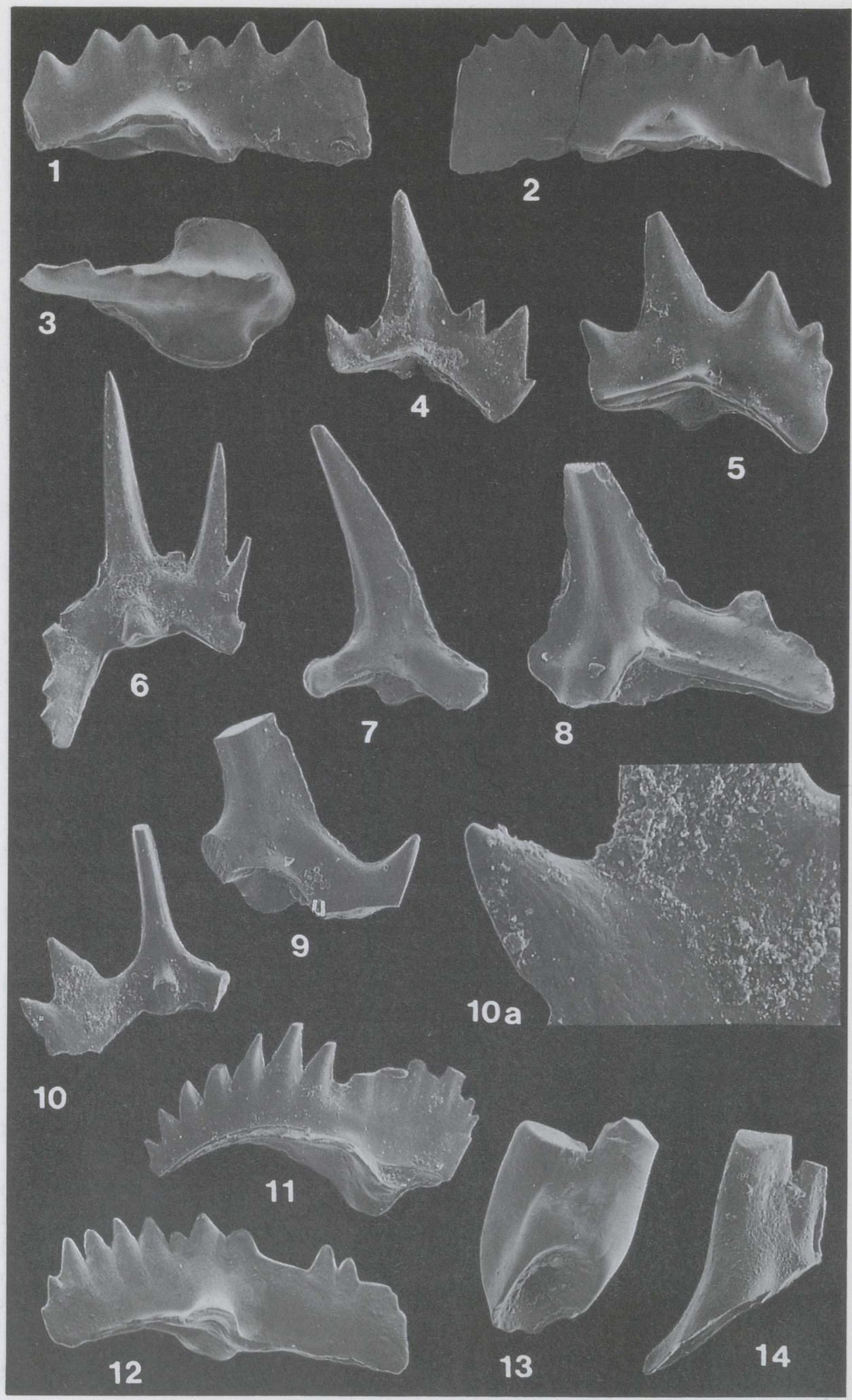


$\mathrm{M}$ element has a prominent cusp and a rather short anterior process. The cusp and denticles have sharp edges. Basal cavity extends as grooves to the ends of the processes, being wider in the anterior process.

S elements have high cusps and supposedly short processes (usually they are broken).

Remarks. The assignment of the species to the genus Amydrotaxis is questioned because of some differences in the apparatus structure, mostly in the $M$ and $S$ elements. The M element is modified, synprioniodiniform, and the Sb element is plectospathodiform rather than lonchodiniform, as supposed in the diagnosis of the genus Amydrotaxis (Klapper \& Murphy 1980). The Pa element of A.? praecox sp. nov. resembles the corresponding element of Ozarkodina linearis (Philip), but the apparatus structure is different.

Occurrence. Loode cliff, sample 6; Ventspils borehole, depth 269.5 m, 273.3 m, $281.9 \mathrm{~m}$; Ruhnu borehole, depth $148.1 \mathrm{~m}, 165.2 \mathrm{~m}$; Sõrve borehole, depth $41.1 \mathrm{~m}$.

\section{Genus Ozarkodina Branson \& Mehl, 1933 \\ Ozarkodina denticulata sp. nov. \\ Plate III, figures 6-8}

Holotype. Pa element, Cn 1614; PI. III, fig. 6.

Type locality. Ruhnu borehole, depth $148.6 \mathrm{~m}$.

Type horizon. Ohesaare Stage, upper Přidoli.

Derivation of name. Latin denticulatus, referring to the slender denticles.

Material. $10 \mathrm{~Pa}$ elements.

Diagnosis. $\mathrm{Pa}$ element (carminate spathognathodiform) with numerous small denticles of almost equal size; blade rather long; basal cavity small, situated centrally.

\section{Explanation of Plate IV}

Figs. 1-10. Amydrotaxis? praecox sp. nov. 1-3, Pa elements; 4, 5, Pb elements; 6, Sb element; 8, M element; 7, 9, Sc element; 10, Sa element. 1, 3, Cn 1617, Cn 1619; Loode cliff, sample 6. 2, Cn 1618, Ruhnu borehole, depth $165.2 \mathrm{~m} .4$, 6, Cn 1620, Cn 1622; Ventspils borehole, depth 281.9 m. 5, 10, Cn 1621, Cn 1626; Ventspils borehole, depth 271.3 m. 7-9, Cn 1623-Cn 1625; Ventspils borehole, depth $273.6 \mathrm{~m}, 289.9 \mathrm{~m} .1,3-5,7 \times 50 ; 2 \times 20 ; 6 \times 30 ; 8 \times 75 ; 9,10 \times 30$; $10 \mathrm{a} \times 35$.

Fig. 11. Oulodus sp., Pa element. Cn 1627; Ventspils borehole, depth $289.9 \mathrm{~m} ; \times 50$.

Fig. 12. Ozarkodina sp., Pa element. Cn 1628; Kolka borehole, depth $180.2 \mathrm{~m} ; \times 30$.

Figs. 13, 14. Streptotaxis? sp. 13, Cn 1629; Ruhnu borehole, depth $170.0 \mathrm{~m} ; \times 40.14, \mathrm{Cn} 1630$; Ingeland 618 borehole, depth $35.5 \mathrm{~m} ; \times 75$. 
Description. A few very characteristic specimens of the Pa element occur in Ruhnu and Hindu boreholes. Blade has many (up to 25) slender, finely striated denticles (Pl. III, fig. 6a). Fusion of denticles translucent in upper half of the blade. A little bigger denticle above the basal cavity may be observed. Anterior part of the blade may be slightly higher than the posterior part. Aboral margin slightly ascends from the basal cavity to the anterior and posterior ends. Basal cavity small, with lobes quite similar to $O z$. remscheidensis, but smaller. White matter defines clearly erect denticle roots and fills about two-thirds of the blade.

$\mathrm{Pb}, \mathrm{M}$, and $\mathrm{S}$ elements supposed to be analogical to $\mathrm{Oz}$. remscheidensis.

Occurrence. Ruhnu borehole, depth 148.6 m, 149.1 m, 152.2 m, 169.3 m; Hindu 653 borehole, depth $48.5 \mathrm{~m}$.

Ozarkodina inordinata sp. nov.

Plate III, figures $1-5$

Holotype. Pa element, Cn 1609; Pl. III, fig. 1.

Type locality. Loode cliff, Sõrve Peninsula of Saaremaa Island.

Type horizon. Ohesaare Stage, upper Přidoli.

Derivation of name. Latin inordinatus, referring to the irregular character of denticles.

Material. About $100 \mathrm{~Pa}$ elements.

Diagnosis. $\mathrm{Pa}$ element with short blade and alternating denticles in the central part.

Description. Pa element (carminate spathognathodiform) with a short and rather high blade. Anterior part is slightly higher, denticulation variable. Above the basal cavity usually a big denticle (cusp) and very small denticles (or open space) occur on both sides of it. Cusp-sized denticle(s), or even higher, may occur on the anterior and posterior parts of the blade. Denticles have fine-striated microstructure (Pl. III, fig. 5a).

Centrally situated basal cavity is relatively wide open and extends as grooves to both ends of the blade. Posterior aboral margin ascends to the posterior-aboral corner. White matter in the root of the cusp reaches the tip of the cavity, diminishing towards the anterior and posterior ends of the blade.

$\mathrm{Pb}, \mathrm{M}$, and $\mathrm{S}$ elements supposed to be analogical to those of $\mathrm{Oz}$. remscheidensis.

Remarks. The Pa element may be comparable with the $\mathrm{Pa}$ element of Ozarkodina wimani (Jeppsson), but differs in the denticulation of the central part of the blade and in having a bigger and more open basal cavity. 
Occurrence. Ohesaare and Loode cliffs; Ohesaare borehole, interval 3.1510.05 m; Kaavi 568 borehole, depth 9.2 m, 25.5 m; Kaavi 571 borehole, depth $11.60 \mathrm{~m}$; Ruhnu borehole, interval 148.8-172.6 m; Kolka borehole, interval 172.7-213.6 m; Ventspils borehole, interval 268.4-365.2 m; Loode borehole, depth 12.9 m, 13.0 m; Kargi 623 borehole, depth 30.5 m, 38.8 m; Ingeland 618 borehole, interval 35.5-45.5 m; Hindu 653 borehole, interval $12.0-35.5 \mathrm{~m}$.

\section{Ozarkodina nasuta (Viira, 1983)}

Plate II, figures 1, 3-5

1974 Ozarkodina confluens n. ssp. A; Fåhraeus, fig. 2 B.

1983 Spathognathodus primus nasutus ssp. n.; Viira, pp. 60-61, 70, pl. VI, figs. 1, 3, 7-13; text-figs. 12-13.

1990 Ozarkodina confluens nasutus Viira, Männik \& Viira, pl. 18, fig. 21.

Holotype. Pa element, Cn 874; Viira 1983, fig. 12.

Type locality. Ohesaare cliff, Sõrve Peninsula of Saaremaa Island. The species ranges throughout the section, except the lowermost $0.8 \mathrm{~m}$.

Type horizon. Ohesaare Stage, upper Přidoli.

Material. Hundreds of specimens of all elements.

Diagnosis. Pa element with very high anterior third of the blade where denticles are usually fused. Remaining two-thirds of the low blade bear small denticles.

Description. Pa element has two clearly different parts in lateral view: very high and thicker anterior third (the poop) with firmly fused denticles, and lower, posterior two-thirds. Posterior edge of the poop usually upright. In lateral view the anterior end is rounded; the denticulated lower part of the blade is slightly arched, so that the posterior end lowers downwards. Aboral line angular, with upwards extending anterior and posterior parts. The posteriormost aboral line may be curved downwards. Basal cavity located centrally. Lobes are small and rounded. Grooves starting from the shallow basal cavity do not reach the ends of the blade. Basal filling has the shape of a rounded plate with sharp anterior and posterior tips. White matter spreads sporadically in the denticle roots and is usually absent in the anterior part of the blade.

$\mathrm{Pb}, \mathrm{M}$, and $\mathrm{S}$ elements are similar to those of $\mathrm{Oz}$. confluens.

Remarks. The diagnosis and description of this species are based on the original description of Spathognathodus (= Ozarkodina) confluens nasutus (Viira, 1983).

Ozarkodina nasuta resembles Ozarkodina confluens gamma morphotype of Klapper \& Murphy (1975) in having big denticles at the anterior end of the blade, but the denticulation of the former is more regular. Some similarity is 
observed also with gamma morphotype specimens Ozarkodina confluens from the Canadian Arctic Archipelago (Uyeno 1980, pl. 1, figs. 16-18, 20, 22, 23). Ozarkodina nasuta is comparable with Lower Devonian Pandorinellina exigua exigua (Philip) in the poop of the blade. It may be presumed that Ozarkodina nasuta was the ancestor of the Pandorinellina group.

Occurrence. In almost all studied sections which pass through the Ohesaare Stage.

\section{ACKNOWLEDGEMENTS}

I am grateful to T. Märss for the permission to use her sample residues to collect additional conodont material. I wish to thank D. Kaljo, P. Männik, and L. Jeppsson for fruitful discussions and constructive reviews of the manuscript. Thanks are extended to K. Ronk for drawings. Financial support was provided by the Estonian Science Foundation (grants Nos. 1935 and 2854).

\section{REFERENCES}

Aaloe, A., Kaljo, D., Klaamann, E., Nestor, H. \& Einasto, R. 1976. Stratigraphical classification of the Estonian Silurian. ENSV TA Toim. Keem. Geol., 25, 38-45 (in Russian).

Bassett, M. G., Kaljo, D. \& Teller, L. 1989. The Baltic region. In A Global Standard for the Silurian System (Holland, C. D. \& Bassett, M. G., eds.), pp. 158-170. National Museum of Wales, Geol. Series No. 9, Cardiff.

Fåhraeus, L. E. 1974. Taxonomy and evolution of Ozarkodina steinhornensis and Ozarkodina optima (Conodontophorida). Geologica Palaeontologica, 8, 29-37.

Gailite, L. K., Ulst, R. J. \& Yakovleva, V. I. 1987. Stratotipicheskie i tipovye razrezy silura Latvii. Zinatne, Riga (in Russian).

Jeppsson, L. 1975. Aspects of Late Silurian conodonts. Fossils Strata, 6.

Jeppsson, L. 1988. Conodont biostratigraphy of the Silurian-Devonian boundary stratotype at Klonk, Czechoslovakia. Geologica Palaeontologica, 22, 21-31.

Jeppsson, L., Viira, V. \& Männik, P. 1994. Silurian conodont-based correlations between Gotland (Sweden) and Saaremaa (Estonia). Geol. Mag., 131, 201-218.

Kaljo, D. L. (ed.). 1970. Silur Éstonii. Valgus, Tallinn (in Russian).

Kaljo, D. L. \& Jürgenson, E. A. 1977. Sedimentary facies of the East Baltic Silurian. In Fatsii $i$ fauna silura Pribaltiki (Kaljo, D. L., ed.), pp. 122-148. Akad. nauk ESSR, Tallinn (in Russian).

Klapper, G. \& Murphy, M. A. 1975. Silurian-Lower Devonian conodont sequence in the Roberts Mountains Formation of central Nevada. Univ. California Publ. Geol. Sci., 3.

Klapper, G. \& Mur hy, M. A. 1980. Conodont zonal species from the delta and pesavis Zones (Lower Devonian) in central Nevada. N. Jb. Geol. Paläont. Mh., H8, 490-504.

Männik, P. \& Viira, V. 1990. Conodonts. In Field Meeting Estonia 1990: An Excursion Guidebook (Kaljo, D. \& Nestor, H., eds.), pp. 84-89. Estonian Acad. Sci., Tallinn.

Märss, T. 1986. Silurian vertebrates of Estonia and West Latvia. Fossilia Baltica, 1. Valgus, Tallinn (in Russian).

Märss, T. 1997. Vertebrates of the Pridoli and Silurian-Devonian boundary beds in Europe. Mod. Geol., 21, 17-41. 
Nestor, H. 1990. Ohesaare cliff. In Field Meeting Estonia 1990: An Excursion Guidebook (Kaljo, D. \& Nestor, H., eds.), pp. 175-178. Estonian Acad. Sci., Tallinn.

Nestor, H. 1997. Silurian. In Geology and Mineral Resources of Estonia (Raukas, A. \& Teedumäe, A., eds.), pp. 89-106. Estonian Acad. Publ., Tallinn.

Nestor, H. \& Einasto, R. 1997. Ordovician and Silurian carbonate sedimentation basin. In Geology and Mineral Resources of Estonia (Raukas, A. \& Teedumäe, A., eds.), pp. 192-204. Estonian Acad. Publ., Tallinn.

Nestor, V. 1992. Chitinozoan diversity dynamics in the East Baltic Silurian. Proc. Estonian Acad. Sci. Geol., 41, 215-224.

Uyeno, T. T. 1980. Stratigraphy and conodonts of Upper Silurian and Lower Devonian rocks in the environs of the Boothia Uplift, Canadian Arctic Archipelago, Part II. Systematic study of conodonts. Geol. Surv. Canada Bull., 292, 39-75.

Verniers, J., Nestor, V., Paris, F., Dufka, P., Sutherland, S. \& Van Grootel, G. 1995. A global Chitinozoa biozonation for the Silurian. Geol. Mag., 132, 651-666.

Viira, V. 1970. Conodonts. In Silur Éstonii (Kaljo, D., ed.), pp. 174-175. Valgus, Tallinn (in Russian).

Viira, V. 1977. Conodonts and their distribution in the Silurian of the East Baltic (Ohesaare, Kunkoai, Ukmerge etc. borings). In Fatsii i fauna silura Pribaltiki (Kaljo, D. L., ed.), pp. 179-192. Akad. nauk ESSR, Tallinn (in Russian).

Viira, V. 1982. Late Silurian shallow and deep water conodonts of the East Baltic. In Ecostratigraphy of the East Baltic Silurian (Kaljo, D. \& Klaamann, E., eds.), pp. 79-88. Valgus, Tallinn.

Viira, V. 1983. Upper Silurian Spathognathus (Conodonts) from Estonia. In Paleontologiya drevnego paleozoya Pribaltiki $i$ Podolii (Klaamann, E., ed.), pp. 41-71. Akad. nauk ESSR, Tallinn (in Russian).

Viira, V. 1994. A new Upper Silurian conodont species from Estonia. Proc. Estonian Acad. Sci. Geol., 43, 32-37.

Viira, V. 1999. Late Silurian conodont biostratigraphy in the northern East Baltic. In Studies on Conodonts: Proceedings of the Seventh European Conodont Symposium (Serpagli, E., ed.). Boll. Soc. Paleontol. Ital. 37, 299-310.

Ziegler, W. 1960. Conodonten aus dem Rheinischen Unterdevon (Gedinnium) des Remscheider sattels (Rheinisches Schiefergebirge). Paläontol. Z., 34, 169-201.

\title{
HILISSILURI (OHESAARE LADE) KONODONDID JA DETORTA TSOON PÕHJA-BALTIKUMIS
}

\author{
Viive VIIRA
}

Hilissiluri konodontide kooslus pärineb Sõrve poolsaare (Saaremaa), Ruhnu saare ja Lääne-Läti puuraukudest ning Ohesaare ja Loode paljandeist. Uuritav fauna haarab konodontide tsonaalse skeemi järgi remscheidensis'e tsooni ülemise, nimelt remscheidensis remscheidensis'e alamtsooni. Detorta tsoon on kitsas intervall nimetatud alamtsoonis. On kirjeldatud kolm uut liiki: Amydrotaxis? praecox sp. nov., Ozarkodina denticulata sp. nov. ja Oz. inordinata sp. nov. Liik $O z$. nasuta (Viira, 1983) oli algselt kirjeldatud $O z$. confluens'i alamliigina. 


\section{Вийве ВИЙРА}

Изучена позднесилурийская фауна конодонтов из буровых скважин на п-ве Сырве (о. Сааремаa), о-ве Рухну и западной Латвии, а также обнажений Охесааре и Лооде. Эта фауна охватывает верхнюю часть зоны remscheidensis, а именно подзону remscheidensis remscheidensis, в пределах которой зона detorta занимает узкий интервал. Описаны три новых вида: Amydrotaxis? praecox sp. nov., Ozarkodina denticulata sp. nov. и $O z$. inordinata sp. nov. Вид Oz. nasuta (Viira, 1983) первоначально был описан в качестве подвида $O z$. confluens. 